MATERIAEY ŹRÓDŁOWE 



\section{REZOLUCJA RADY PRAW CZLOWIEKA ONZ PRZEDŁUŻAJĄCA MANDAT GRUPY ROBOCZEJ DS. PRAW CZŁOWIEKA I BIZNESU Z DNIA 22 CZERWCA 2017 R. NR A/HRC/RES/35/ $7^{1}$}

Rezolucja przyjęta przez Radę Praw Człowieka w dniu 22 czerwca 2017 r.

35/7. Biznes i prawa człowieka: mandat Grupy Roboczej ds. praw człowieka i korporacji transnarodowych oraz innych przedsiębiorstw

Rada Praw Człowieka,

Przywołujac rezolucje Rady Praw Człowieka nr 8/7 z dnia 18 czerwca 2008 r., nr 17/4 z dnia 6 lipca 2011 r., nr 21/5 z dnia 27 września 2012 r., nr 26/22 z dnia 27 czerwca 2014 r. i nr 32/10 z dnia 30 czerwca 2016 r. oraz rezolucję Komisji Praw Człowieka nr 2005/69 z dnia 20 kwietnia 2005 r., w sprawie praw człowieka i korporacji transnarodowych oraz innych przedsiębiorstw,

Przywołując w szczególności rezolucję nr 17/4 Rady Praw Człowieka przyjmującą w drodze konsensusu Wytyczne dotyczące Biznesu i Praw Człowieka, ustanawiające właściwe ramy mające na celu zapobieganie i reagowanie na negatywne skutki działalności gospodarczej w zakresie praw człowieka w oparciu o trzy filary dokumentu ramowego Narodów Zjednoczonych „Chronić, Szanować i Naprawiać”2,

Przywołujac swoje rezolucje nr 5/1 w sprawie rozwoju instytucjonalnego Rady Praw Człowieka i nr 5/2 w sprawie Kodeksu Postępowania dla Upoważnionych w Zakresie Procedur Specjalnych Rady, obie z 18 czerwca 2007 r., i podkreślając, że mandatariusze powinni wykonywać swe obowiązki zgodnie z tymi rezolucjami i załącznikami do nich,

1 Resolution adopted by the Human Rights Council on 22 June 2017 extending the mandate of the Working Group on the issue of human rights and transnational corporations and other business enterprises, Human Rights Council resolution adopted during thirty-fifth session, 6-23 June 2017, U.N. Doc. A/HRC/RES/35/7.

A/HRC/17/31, aneks. 
Podkreślając, że obowiązek i główna odpowiedzialność za wspieranie i ochronę praw człowieka i podstawowych wolności spoczywa na Państwie,

Zaznaczając, że korporacje transnarodowe i inne przedsiębiorstwa są zobowiązane do przestrzegania praw człowieka,

Uznając poczynione postępy i ciągłe wysiłki na rzecz wdrożenia $\mathrm{Wy-}$ tycznych przez niektóre państwa, przedsiębiorstwa, organizacje międzynarodowe i członków społeczeństwa obywatelskiego, a także znaczenie inicjatywy Narodów Zjednoczonych „Global Compact”, między innymi w promowaniu Wytycznych,

Uznając również wartościową rolę jaką odgrywa społeczeństwo obywatelskie, w tym organizacje pozarządowe, w promowaniu odpowiedzialności za naruszenia praw człowieka związane z działalnością gospodarczą oraz w zwiększaniu świadomości w zakresie wpływu i ryzyka niektórych przedsiębiorstw i ich działalności na prawa człowieka,

Uwzględniajac rolę jaką mogą odgrywać krajowe plany działania i inne dokumenty ramowe dotyczące biznesu i praw człowieka, jako narzędzia promujące kompleksową i skuteczną implementację Wytycznych,

Zaniepokojona prawnymi i praktycznymi przeszkodami w zakresie dostępu do środków zaradczych za naruszenia praw człowieka związane z działalnością gospodarczą, które mogą pozostawić poszkodowanych bez możliwości podjęcia skutecznych środków zaradczych, w tym w drodze sądowej i pozasądowej, oraz uznając, że należy dokładniej zbadać, w jaki sposób odpowiednie ramy prawne mogą zapewnić skuteczniejsze środki zaradcze dla poszkodowanych osób i społeczności,

Przypominajac rolę Grupy Roboczej do spraw praw człowieka i korporacji transnarodowych oraz innych przedsiębiorstw w promowaniu skutecznego wdrażania Wytycznych i szukania możliwości zwiększenia dostępu do skutecznych środków zaradczych,

Uznając, że doroczne Forum Biznesu i Praw Człowieka stanowi cenną okazję do promowania dialogu i współpracy w kwestiach związanych z nabywaniem doświadczeń z zakresu biznesu i praw człowieka, w tym wyzwań, przed którymi stają określone sektory, środowiska operacyjne lub w odniesieniu do określonych praw lub grup, jak również identyfikowaniu dobrych praktyk,

Uznając również znaczenie budowania potencjału Rządów, przedsiębiorstw, społeczeństwa obywatelskiego i innych zainteresowanych stron, by lepiej zapobiegać naruszeniom praw człowieka związanym z działalnością gospodarczą, zapewniać skuteczne środki zaradcze i zarządzać 
wyzwaniami w dziedzinie biznesu i praw człowieka oraz że system Narodów Zjednoczonych ma do odegrania ważną rolę w tym zakresie,

Przywotując poglądy i zalecenia organów traktatowych Narodów Zjednoczonych do spraw praw człowieka, w tym uwagi ogólne dotyczące kwestii praw człowieka i korporacji transnarodowych oraz innych przedsiębiorstw, takie jak uwagi ogólne nr 16 (2013) Komitetu Praw Dziecka,

Przyjmując z zadowoleniem przyjęcie przez Zgromadzenie Ogólne, rezolucją nr 70/1 z dnia 25 września 2015 r. Programu Działań na Rzecz Zrównoważonego Rozwoju do roku 2030, a w tym kontekście, w szczególności jego pkt 67,

Odnotowując przyjęcie przez Radę Administracyjną Międzynarodowej Organizacji Pracy w marcu 2017 r. zrewidowanej Trójstronnej Deklaracji Zasad Dotyczących Przedsiębiorstw Wielonarodowych i Polityki Społecznej, która uwzględnia między innymi Wytyczne,

1. Przyjmuje prace Grupy Roboczej do spraw praw człowieka i korporacji transnarodowych oraz innych przedsiębiorstw $\mathrm{w}$ wypełnianiu jej mandatu i zauważa jej rolę na forach regionalnych i rolę konsultacyjną w zakresie omawiania wyzwań i wniosków wyciągniętych z wdrażania Wytycznych dotyczących Biznesu i Praw Człowieka z Państwami i innymi zainteresowanymi stronami, w kontekście regionalnym;

2. Uznaje, że skuteczne wdrażanie Wytycznych powinno obejmować szeroki zakres obszarów polityki publicznej przy udziale odpowiednich zainteresowanych stron oraz zachęcać wszystkie Państwa do podjęcia działań implementujących postanowienia Wytycznych, w tym poprzez opracowanie krajowego planu działania lub innych dokumentów ramowych;

3. Wzywa wszystkie przedsiębiorstwa do wywiązania się z obowiązku przestrzegania praw człowieka zgodnie z Wytycznymi;

4. Odnotowuje sprawozdanie Grupy Roboczej w sprawie wyzwań i możliwości dla małych i średnich przedsiębiorstw w zakresie wdrażania Wytycznych ${ }^{3}$ i jej analizę dotyczącą współpracy transgranicznej między państwami $\mathrm{w}$ odniesieniu do poszanowania prawa $\mathrm{w}$ zakresie biznesu i praw człowieka ${ }^{4}$, przygotowane zgodnie z rezolucją Rady Praw Człowieka nr 32/10;

5. Przyjmuje z zadowoleniem wysiłki Grupy Roboczej w zakresie gromadzenia i rozpowszechniania informacji na temat trwających procesów

$\begin{array}{ll}3 & \mathrm{~A} / \mathrm{HRC} / 35 / 32 . \\ 4 & \mathrm{~A} / \mathrm{HRC} / 35 / 33 .\end{array}$ 
służących opracowywaniu krajowych planów działania i innych odpowiednich informacji na temat ogólnych postępów we wdrażaniu Wytycznych i w związku z tym zachęca Państwa i wszystkie zainteresowane strony do przekazywania informacji i podjęcia współpracy z Grupą Roboczą nad ich krajowymi planami działania i innymi odpowiednimi inicjatywami oraz nad wdrażaniem tych zobowiązan;

6. Wyraża uznanie dla wytycznych przygotowanych przez Grupę Roboczą w zakresie opracowania i wdrożenia skutecznych krajowych planów działania lub innych dokumentów ramowych, w tym w odniesieniu zarówno do dostępu do sądowych, jak i pozasądowych środków ochrony prawnej;

7. Zachęca Grupę Roboczą do promowania dobrych praktyk i określania wyzwań związanych z wdrażaniem Wytycznych;

8. Przyjmuje z zadowoleniem rolę Grupy Roboczej w prowadzeniu trzydniowych dorocznych Forów Biznesu i Praw Człowieka;

9. Postanawia, że Grupa Robocza będzie kierować pracami Forum i przygotowywać jego coroczne spotkania, a także zachęca Grupę Roboczą do przewodniczenia Forum i do przedłożenia sprawozdania z obrad i zaleceń tematycznych Forum do rozpatrzenia Radzie Praw Człowieka;

10. Przyjmuje z zadowoleniem, że głównym tematem organizowanego w 2017 r. Forum Biznesu i Praw Człowieka jest „Ułatwienie dostępu do środków zaradczych”, ponieważ może to umożliwić dokonanie oceny i wskazanie dalszych sposobów wdrażania trzeciego filaru Wytycznych;

11. Postanawia przedłużyć mandat Grupy Roboczej do spraw praw człowieka oraz korporacji transnarodowych i innych przedsiębiorstw, w sposób określony w rezolucji Rady Praw Człowieka nr 17/4, na okres trzech lat;

12. Zwraca się z prośbq do Grupy Roboczej, zgodnie z jej mandatem, o zwrócenie szczególnej uwagi na wdrażanie Wytycznych w kontekście Programu Działań na Rzecz Zrównoważonego Rozwoju do roku 2030;

13. Zachęca wszystkie Państwa, odpowiednie agencje Narodów Zjednoczonych, fundusze i programy, organy traktatowe i podmioty społeczeństwa obywatelskiego, w tym organizacje pozarządowe, a także przedsiębiorstwa publiczne i prywatne do pełnej współpracy z Grupą Roboczą $\mathrm{w}$ ramach wykonywanego mandatu, między innymi, poprzez udzielanie odpowiedzi na przekazywane komunikaty, jak to przewidziano w punkcie 6 lit. b) rezolucji nr 17/4, a w przypadku Państw - na wyrażanie zgody na wizyty Grupy Roboczej;

14. Zachęca organizacje międzynarodowe i regionalne do konsultowania się z Grupą Roboczą podczas formułowania lub rozwijania odpowied- 
nich polityk i instrumentów oraz zachęca Grupę Roboczą do dalszej ścisłej współpracy z właściwymi organami Narodów Zjednoczonych, w tym $\mathrm{z}$ organami traktatowymi i procedurami specjalnymi;

15. Podkreśla znaczenie dialogu i analizy zainteresowanych stron, tak aby utrzymać i wykorzystać dotychczasowe wyniki w zapobieganiu przypadkom naruszeń praw człowieka związanych z działalnością gospodarczą i im przeciwdziałać, a także by informować o dalszych działaniach Radę Praw Człowieka;

16. Przyjmuje z zadowoleniem wysiłki podejmowane przez krajowe instytucje zajmujące się prawami człowieka w celu zwiększenia ich zdolności do wspierania odpowiedzialności przedsiębiorstw, w tym poprzez wdrażanie Wytycznych przez wszystkie zainteresowane strony;

17. Przypomina sprawozdanie Sekretarza Generalnego w sprawie wyzwań, strategii i rozwoju w zakresie wdrażania rezolucji nr 21/5 przez system Narodów Zjednoczonych, w tym programów, funduszy i agen$\mathrm{cji}^{5}$, oraz zawarte $\mathrm{w}$ nim zalecenia, podkreślając potrzebę wprowadzenia programu działań na rzecz biznesu i praw człowieka oraz Wytycznych w całym systemie Narodów Zjednoczonych;

18. Zwraca się do Sekretarza Generalnego i Wysokiego Komisarza Narodów Zjednoczonych do spraw Praw Człowieka o zapewnienie wszelkich zasobów i wsparcia koniecznego do skutecznego wypełniania swojego mandatu przez Grupę Roboczą, w tym jej roli w kierowaniu pracami Forum Biznesu i Praw Człowieka;

19. Zwraca się również do Sekretarza Generalnego i Wysokiego Komisarza o zapewnienie Forum, w sposób przejrzysty, wszystkich niezbędnych usług i udogodnień, mając na uwadze rosnące zainteresowanie udziałem w Forum i zwracając szczególną uwagę na równowagę regionalną oraz zapewniając uczestnictwo pokrzywdzonym osobom i społecznościom.

20. Postanawia kontynuować rozważania nad tym zagadnieniem zgodnie ze swoim rocznym programem pracy.

34. spotkanie 22 czerwca 2017 r.

[Przyjęta bez głosowania]

tłum. z j. ang. Łukasz Dawid Dąbrowski

5 A/HRC/26/20.

Dr, Szkoła Główna Handlowa w Warszawie. 
